\title{
An Analysis of Demand for Microfinance in Sri Lanka
}

\author{
W.M.S.M. Wijesinghe ${ }^{1}$ \& W.D.N.S.M. Tennakoon ${ }^{2}$ \\ ${ }^{1,2}$ Department of Business Management \\ Faculty of Business Studies \& Finance \\ Wayamba University of Sri Lanka \\ Kuliyapitiya \\ SRI LANKA \\ sumudunimadhushika@gmail.com ${ }^{1}$,tennakoon@wyb.ac.lk ${ }^{2}$
}

\begin{abstract}
Necessity of microfinance services is upraising with the increased complexity of rural life style. Economic pattern of rural communities and the performance of informal financial sector are two cornerstones of the modern microfinance services. It is expected that the demand for microfinance will be increased as the complexity of rural life thrived. Yet, a downward trend is noted in the demand for microfinance by the rural community of Sri Lanka with the introduction of social benefit programmes particularly, the "Samurdhi" Programme. Thus, the motive of this study was to empirically evaluate the factors affecting the demand for microfinance. In particular, it was based on the clients of Samurdhi Prajamula Banking Societies (SPBSs) in Diganwewa Division, Puttalam District of Sri Lanka. The study was quantitative and used the survey research method. The sample was randomly drawn from Samurdhi beneficiaries who are currently the members of SPBSs. The data were gathered by administering a close-ended questionnaire while univariate and bivariate analysis analysed them. The results indicated that the general literacy \& income of potential borrowers and also receipt of social benefit by the potential borrowers are significantly predicting the intention to obtain microfinance. Additionally, demand for loan securities, service features and interest charged for the microfinancing facilities are affecting the demand for microfinance. Among the factors related to borrower, literacy level and income of them found positively and significantly affecting the microfinance demand. Yet, a negative influence was noted with respect to receipt of social benefits on the demand for microfinance. All the factors, except service features of the credit facility, negatively affecting the demand for microfinance.
\end{abstract}

Keywords: Microfinance, Demand, Social benefit funds, Rural community, Samurdhi Programme

\section{INTRODUCTION}

Alleviation of poverty is first and foremost Sustainable Development Goals (SDGs) by the United Nations (UN, 2015), so do Sri Lanka. However, the government is facing a great challenge in poverty alleviation especially in creating appropriate employment opportunities for the growing labour force. It has been accepted universally that microfinance is an effective tool in creating employment, especially among 
women and landless. Experiences from many developing countries show that microfinancing has significantly contributed towards alleviating poverty. Therefore, encouraging microfinancing and development of microenterprises have been one of the key strategies of the governments in the past. There are number of governmental, non-governmental, private, co-operative organizations and community-level groups involved in providing microfinance in Sri Lanka. Economically less-privileged people manage to mobilize resources to develop their enterprises and their dwellings slowly over time. Financial services could enable the poorer to leverage their initiative, accelerating the process of building incomes, assets and economic security etc. However, conventional finance institutions seldom lend down-market to serve the needs of low-income families and women-headed households. They are very often denied access to credit for any purpose, making the discussion of the level of interest rate and other terms of finance irrelevance. Resultantly, so much of unaffordable terms of loan itself leads to the lack of access to credit. The lack of access to credit for the impoverished people is attributable to practical difficulties arising from the discrepancy between the mode of operation followed by financial institutions, and to the economic characteristics \& financing needs of low- income households (Omboi and Wangai, 2011). For example, commercial lending institutions require that borrowers have a stable source of income out of which principal and interest can be paid back according to the agreed terms. However, the income of many self-employed households is not stable, regardless of its size. A large number of small loans are needed to serve the poor, but lenders prefer dealing with large loans in small numbers to minimize administration costs (Vetrivel and Kumarmangalam, 2010). They also look for collateral with a clear title - which many lowincome households do not have. In addition, bankers tend to consider low income households a bad risk imposing exceedingly high information monitoring costs on operation. The primary problem that poor people face as money managers is to gather a 'usefully large' amount of money. Building a new home may involve saving and protecting diverse building materials for years until enough are available to proceed with construction. Children's schooling may be funded by buying chickens and raising them for sale as needed for expenses, uniforms, bribes etc. Because all the value is accumulated before it is needed, this money management strategy is referred to as 'saving up'. Often, people don't have enough money when they face a need, so they borrow. A poor family might borrow from relatives to buy land, from a moneylender to buy rice, or from a microfinance institution to buy a sewing machine. There are various obstacles to access formal financial sector for people who are too poor (Mpuga, 2010). So, the needy people are discouraged to reach financial services from formal financial sector (Vetrivel and Kumarmangalam, 2010). And also, low-income households had to suffer within more traps of debt. It seems to be that the microfinance has evolved with the help of continuous efforts towards 
experiments and innovations of microfinance services in various countries because of the need of the most efficient and effective mechanism which is the better way of delivering financial services with requirements of the needy people.

Microfinance institutions can broaden their resource base by mobilizing savings, accessing capital markets, loan funds and effective institutional development support. A logical way to tap capital market is securitization through a corporation that purchases loans made by microenterprise institutions with the funds raised through the bond issuance on the capital market (Chen, Rasmussen and Reille, 2010). Savings facilities make large scale lending operations possible. On the other hand, studies also show that the poor operating in the informal sector do save, although not in financial assets, and hence value access to client-friendly savings service at least as much access to credit (Chen, Rasmussen and Reille, 2010). Savings mobilization also makes financial institutions accountable to local shareholders.

Therefore, adequate savings facilities both serve the demand for financial services by the customers and fulfil an important requirement of financial sustainability to the lenders. Microfinance institutions can either provide savings services directly through deposit taking or make arrangements with other financial institutions to provide savings facilities to tap small savings in a flexible manner.

\subsection{Microfinance}

The purpose of microfinancing is only to provide the capital to economically improvised people and reducing the poverty level. These institutions are driven by the goal of providing the financial services to those people who are not capable to gain the formal credit facilities (Modoran, Grashof, Fernando and Tennakoon, 2009; Chen, Rasmussen and Reille, 2010). Microfinance has emerged as a larger movement whose object is to form a world in which as everyone, especially the poor and socially marginalized people and households have access to wide range of affordable, high quality financial products and services, including not just credit but also savings, insurance, payment services, and fund transfers (Chowdhury, 2009). Many of those who promote microfinance generally believe that such access will help poor people out of poverty. For many, microfinance is a way to promote economic development, employment and growth through the support of micro entrepreneurs and small businesses. For others it is a way for poor to manage their finances more effectively and take advantage of economic opportunities while managing the risks (Chen, Rasmussen and Reille, 2010; Chowdhury, 2009). To the extent that microfinance institutions become financially viable, self-sustaining, and integral to the communities in which they operate, they have the potential to attract more resources and expand services to clients. Although there is demand for credit by impoverished people and women at market interest rates, the 
volume of financial transaction of microfinance institution must reach a certain level before their financial operation becomes self-sustaining (Kausar, 2013). In other words, although microfinance offers a promising institutional structure to provide access to credit to the needy people, the scale problem needs to be resolved so that it can reach the vast majority of potential customers who demand access to credit at market rates. The question then is how microenterprise lending geared to providing short term capital to small businesses in the informal sector can be sustained as an integral part of the financial sector and how their financial services can be further expanded using the principles, standards and modalities that have proven to be effective. The term 'microfinance' refers to small scale financial services, primarily credit and savings to the economically active low income clients to produce goods and provide services (Hermes and Lensink, 2007). In addition to credit and savings, some microfinance institutions provide other financial services such as micro money transfer and micro insurance and also provide social intermediation such as development of social capital (through groups formation, training in financial and enterprise management and development of management capabilities) and external support services (Wrenn, 2007). The general features of microfinance are, small size of the loan not based on collateral or legally enforceable contracts, group guarantee, compulsory \& voluntary savings, informal appraisal of borrowers \& investments and access to repeat \& bigger loans based on repayment performances (Chen, Rasmussen and Reille, 2010). In general terms, microfinance is the provision of a broad range of financial services to those excluded from the formal financial system. Microfinance lending technologies are developed primarily around an analysis of clients' character, cash flows, and commitment to repay a loan, rather than on collateral requirement characteristic of asset-based lending technologies of traditional banks.

\subsection{Microfinance in Sri Lanka}

The formal rural financial sector in Sri Lanka comprises a large number of Micro Financial Institutions (MFIs). These MFIs, play an important role in meeting the rural credit needs in rural sector in Sri Lanka (Modoran, Grashof, Fernando and Tennakoon, 2009). MFIs have gained an increasing share of financial assets, which has been particularly helpful for satisfying the growing demand for loans and advances in economically improvised people in the country. However, performance of MFIs in Sri Lanka is less than satisfactory and highly criticized today (Modoran, Grashof, Fernando and Tennakoon, 2009; Fernando and Madurapperuma, 2009; Zeller, 1999). Poor performance has been attributed to poor management of assets and consequently, the sustainability of these institutions is uncertain (Fernando and Madurapperuma, 2009). Moreover, an attention to the efficiency of MFIs in Sri Lanka is more concern to the general public given collapses of several formal and informal MFIs. So, microfinance is increasingly being considered as one 
of the most effective tools of reducing poverty.

Sri Lanka's formal rural finance sector is characterized by a diverse set of institutions comprising of Thrift and Credit Cooperative Societies (TCCSs), Cooperative Rural Banks (CRBs), Regional Development Banks (RDBs), and Samurdhi Banking Societies (SBSs). CRBs and TCCSs account for nearly half the microcredit market in terms of active borrowers and but many of the banks are unsustainable (Annual Report of SBS, 2014). Samurdhi with a vast outreach, is a social benefit government programme focused on alleviating poverty. Despite the long history and large number of institutions providing microfinance services particularly to the poor, there is limited knowledge on the impact of microfinance, reaching the poorest in Sri Lanka. The microfinance movement in Sri Lanka dates as far back as 1906 with the establishment of TCCSs under the Co-operative Societies Ordinance introduced by the British colonial administration. These were the first credit co-operatives to be established in Sri Lanka. The network of TCCSs was weak and in decline by the late 1970s and there were plans to wind up many societies while later the same were re-organized under a new brand: SANASA.

The Government plays a key role in the delivery of microfinance services. Various Government initiatives in the microfinance sector have been implemented from time to time. The Samurdhi Development Programme (SDP) was introduced in 1995, replacing the previous Janasaviya Programme, one of the largest of these initiatives. The Program had a savings and credit component which was administered through the network of 1,038 member-owned, SBSs. Commencing in 1985, the government established 17 Regional Rural Development Banks (RRDBs) through a parliament act. These institutions were given the task of reaching rural areas and smallholders who lacked access to formal financial services. These are of particular bank category registered under the governance of the Central Bank of Sri Lanka. By aggregating several RRDBs in to larger ones, six Regional Development Banks were formulated. Implementation of special microfinance programs was supported directly by the incorporation of these banks. Thereafter, establishment of specialized banks of such nature were commenced. These banks of special purposes, time-to-time staged social beneficial programmes. Janasaviya, Samurdhi program and Gamidiriya were outstanding programs among them. Supply of funds to microfinance institutions which are employed at small lending activities established under Janasavi trust fund in 1991 was commenced. So, a mechanism that is procured funds easily to microfinance institutions was created. The government's support too was received in promoting the activities of that field as the world recognition for microfinance services as an effective tool for poverty alleviation increases. During late 1980s and early 1990s, the entry of several local and international NGOs into the microfinance business was improved. Many of these NGOMFIs originally combined microfinance activities with other social and community development 
activities. Setting organizations aggregated the people of rural areas in to different community development programmes such as Sarvodaya Sramadana Campaign, and Lanka Mahila Samithi. Afterwards, NGOs too seemed engage in community development activities in rural areas. In 1980s, these rural organizations were accommodated to distribute credit and collect the deposits by various organizations. Therein, after 1980s, a remarkable growth of microfinance sector was noted (IPS, 2005)

\subsection{Samurdhi Prajamula Bank (SPB)}

Sri Lanka Samurdhi Authority established under the Samurdhi Authority Act No. 30 of 1995. It started to function with effect from 01st February 1996.The Samurdhi Movement which has the building of a prosperous Sri Lanka through a comprehensive development among disadvantaged groups in the society as its mission has kept numerous progressions as a pilot project towards sustainable development. Thus, it has contributed to bring in positive changes in the economic and social levels of low income families. This stipulated that the main functions of the Samurdhi National Programme are to improve; the economic \& social conditions of youth, women, \& disadvantaged groups of the society by broadening their opportunities for income enhancement \& employment; integrating them into economic \& social development activities; linking family level economic activities with community development projects at village, district, divisional, \& provincial levels; mobilizing their participation in the planning \& management of projects \& schemes for their upliftment; fostering cooperation among them; promoting savings amongst them and assisting them to obtain credit facilities,; facilitating the delivery of inputs \& services of government departments, public corporations, local authorities, private sector organizations, \& nongovernmental organizations to beneficiaries of the programme; and to implement the governmental poverty alleviation programmes.

The administration of the program was armed by the Ministry of Samurdhi, Youth, and Sports. Three departments within the ministry coordinate various Samurdhi functions namely, the Department of Poor Relief, the Department of the Commissioner General of Samurdhi, and the Samurdhi Authority. These institutions offer small to medium volume credit facilities mostly to their members who can't afford collaterals to get loans from other financial institutions. Additionally, they offer various deposit catagories such as Member's deposits, Non member's deposits, Group deposits, Kekulu (Minor's accounts) deposits, Sisuraka, and Diriya Matha deposit. On averrage, these institutions satisfy amost all the fiancialng needs of the rural cummmity at their satisfaction.

From the theoretical and piratical perspectives, it is important to identify the way in which microfinance links with human life of rural community. Moreover, any further development in this field needed to back by the understanding on it in terms demand 
for microfinance and the drivers of it. Additionally, issues related to microfinancing of the members of SPBSs should be addressed in light of the knowledge on why they have asked / not asked for microfinancing. The role of field officers here in offering a good service is also not clear for policymakers. Intervention of other microfinancing institutions also yet to study. Specially, the impact of social benefit funds given to the members of Samurdhi programme has received the attention of neither administrators nor the researchers. Resultantly, we know very little about the status of the microfinancing taking place among the rural community, in terms of its drivers. Despite these concerns only few studies have been conducted to ascertain the demand for microfinance through SBs.

Necessity for microfinance services has been increasing along with the swelling complexity of rural lives (Modoran, Grashof, Fernando and Tennakoon, 2009; Tilakaratna, Wickramasinghe and Kumara, 2005).

Although it seems that there is a growth in the demand for microfinance by the rural community, no numerical evidences support that claim. Additionally, informal discussions that the researchers had with the field officers also suggest that there is a drop in the demand for microfinance by the rural people. Particularly, the demand for microcredits by the SBSs in Diganwewa Division showing a downward trend over the last few years (Table 1$)$.
Table 1. Percentage of Credit Growth

\begin{tabular}{|l|c|c|c|}
\hline \multirow{1}{*}{$\begin{array}{c}\text { Loan } \\
\text { category }\end{array}$} & \multicolumn{3}{|c|}{ Growth of credit granted } \\
\cline { 2 - 4 } & $\mathbf{3 1 / 1 2 / 1 4}$ & $\mathbf{3 1 / 1 2 / 1 5}$ & $\mathbf{3 1 / 1 2 / 1 6}$ \\
\hline $\begin{array}{l}\text { Self- } \\
\text { eemployment }\end{array}$ & $38 \%$ & $32 \%$ & $25 \%$ \\
\hline $\begin{array}{l}\text { Agricultura1 } \\
\text { loans }\end{array}$ & $41 \%$ & $36 \%$ & $27 \%$ \\
\hline $\begin{array}{l}\text { Housing } \\
\text { loans }\end{array}$ & $25 \%$ & $21 \%$ & $16 \%$ \\
\hline
\end{tabular}

Source: Annual reports - SPB Diganwewa

All categories of granted credits over the three years showed a downward trend. Therefore, it is important to identify the factors driving the lowered demand for credits facilities. Accordingly, this study aimed at detecting the factors affecting the microfiance demand in the context of SPBSs.

Specifically, it looked in how the borrower's income, literacy, receipts of social benefit funds (Samurdhi), and the service features of the lending organization, interest charged for the facilities \& demand for loan securities affect the demand for microfinance. Findings would be beneficial to SBSs in specific and to other microfinance companies in general in shaing their lending plans and strategies. Further studies will also be encouraged in the feld of mcrofanance within the Sri lankan context.

The conceptual framework of the study expected to address the identified theoretical and empirical gaps in the existing literature. The hypothesized relationships and the connecting variables of the conceptual framework are shown by the figure 1 . 


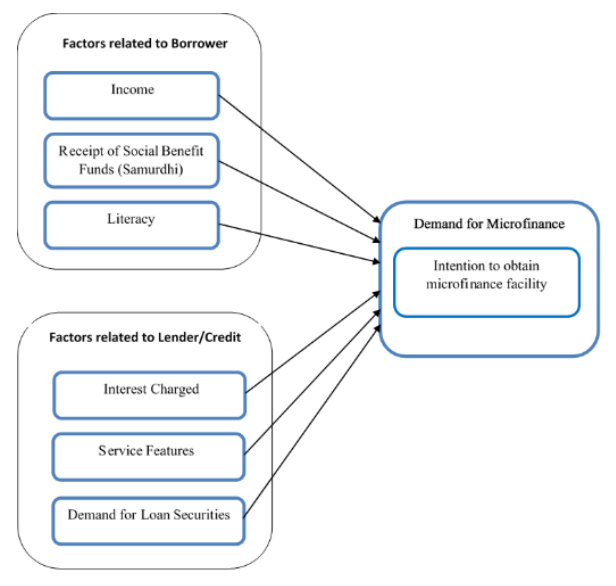

Figure 1. Conceptual Framework

As per the conceptual framework, two groups of factors assumed to be affecting the microfinance demand, namely, factors related to the borrower and the factors related to the lender/credit facility. Based on the conceptual framework and prevailing literature review, the following hypotheses were developed to address the research problem.

H1: The income of the borrower affects the demand for microfinance

H2: Receipt of Social benefit funds (Samurdhi) by the borrower affects the demand for microfinance

$\mathrm{H} 3$ : The literacy of the borrower affects the demand for microfinance

H4: The interest charged for the credit facility affects the demand for microfinance

H5: The service features of the credit facility affect the demand for microfinance

H6: The demand for loan securities by the lender affects the demand for microfinance
The methodological approach adopted by the study is elaborated next.

\section{METHODS}

This study tested the factors influencing demand for microfinance services through SPBSs with reference to the Diganwewa Division, of Puttalam District of Sri Lanka. Diganwewa Division consists of six Grama Niladhari Divisions namely, Eliwitiya, Kumarakattuwa, Dematapitiya, Diganwewa, Mukkandaluwa,and Karukkuliya.

The study followed the deductive reasoning. and quantitative approach in reaching research objectives. It employed a filed survey in gathering data. Six independent variables, under two categories (1. Factors related to borrower: i. Income ii. Literacy, \& iii. Receipt of social benefit funds 2 . Factors related to lender/ credit: i. Interest charged, ii. Service features, \& iii. Demand for loan securities) were tested against the dependent variable: demand for microfinance which was assessed through the respondent's intention to obtain microcredit facilities (Figure 1). The study was performed as a crosssectional study where the unit of analysis was individuals who are the members of SPBSs. The target population of the study was the members of SBSs for which accurate figures were not presented with respect to entire Sri Lanka. Hence, an unknown population was assumed. The sample size as 132 from the population at a 95\% level of confidence and the margin error 5\% (Saunders, Lewis, and Thornhill, 2005). Using simple random sampling 
technique, sample items were drawn from list of member IDs of SPBSs. Survey instrument was a selfadministrative questionnaire of 28 items ( 3 items $x 7$ variables +7 items for demographic variables). Response scale was a 5- point Likert scale ranging from 1 to 5 in which " 1 " denoted "Strongly Disagree" and "5" denoted "Strongly Agree". Instrument showed sound measurement properties in terms of reliability and validity. Internal consistency of all the instruments evidenced to be high and well above the standard (Cronbach Alpha coefficients > 0.7) (table 2).

Table 2. Reliability Statistics of the Instruments

\begin{tabular}{|l|c|c|}
\hline \multicolumn{1}{|c|}{ Variable } & $\begin{array}{c}\text { Cronbach's } \\
\text { Alpha }\end{array}$ & $\begin{array}{c}\text { No of } \\
\text { items }\end{array}$ \\
\hline Income & 0.877 & 3 \\
\hline Literacy & 0.701 & 3 \\
\hline $\begin{array}{l}\text { Receipt of social } \\
\text { benefit funds }\end{array}$ & 0.804 & 3 \\
\hline $\begin{array}{l}\text { Demand for loan } \\
\text { securities }\end{array}$ & 0.882 & 3 \\
\hline Interest charged & 0.849 & 3 \\
\hline $\begin{array}{l}\text { Service features } \\
\text { Intention to obtain } \\
\text { credit facility }\end{array}$ & 0.797 & 3 \\
\hline
\end{tabular}

Face validity ensured that the instruments were well-formed and were free of grammatical and language errors. To summarize and analysis data, MS Excel and SPSS statistics software packages used. General information has been codified, quantified, analysed and evaluated using the SPSS. Descriptive statistics, Correlation analysis and regression analysis were used in arriving the conclusions. The correlation and regression results were interpreted based on Cohen (1992).

\section{RESULTS}

The demographic profiles of the respondents are examined in observing the sample characteristics (Table 3).

Table 3. Demographic Profile of the Sample

\begin{tabular}{|c|c|c|}
\hline Variable & $\mathbf{N}$ & $\%$ \\
\hline \multicolumn{3}{|l|}{ Gender } \\
\hline Male & 49 & 37 \\
\hline Female & 83 & 63 \\
\hline \multicolumn{3}{|l|}{ Age (years) } \\
\hline$<25$ & 8 & 6 \\
\hline $26-35$ & 44 & 33 \\
\hline $36-45$ & 66 & 50 \\
\hline$>45$ & 14 & 11 \\
\hline \multicolumn{3}{|l|}{ Marital Status } \\
\hline Single & 9 & 7 \\
\hline Married & 123 & 93 \\
\hline \multicolumn{3}{|l|}{ Employment } \\
\hline Employed & 23 & 17 \\
\hline Self-employed & 63 & 48 \\
\hline Owned a business & 22 & 17 \\
\hline Other & 24 & 18 \\
\hline \multicolumn{3}{|l|}{ Education Level } \\
\hline Primary Level & 18 & 14 \\
\hline $\begin{array}{l}\text { Ordinary Level } \\
\text { (G.C.E. O/L) }\end{array}$ & 76 & 58 \\
\hline $\begin{array}{l}\text { Secondary Level } \\
\text { (G.C.E. A/L) }\end{array}$ & 38 & 29 \\
\hline \multicolumn{3}{|l|}{ Income Level } \\
\hline$<15,000$ & 55 & 42 \\
\hline $15,000-25,0000$ & 62 & 47 \\
\hline $25,000-35,000$ & 12 & 9 \\
\hline$>35,000$ & 3 & 2 \\
\hline
\end{tabular}

Majority of the respondents was female $(63 \%)$. It is noteworthy to mention that the rural women 
involvement in banking and financing activities are greater compared to that of male counter partners of them (Herath, Guneratne and Sanderatne, 2015). Additionally, the sample represented vastly by middle age respondents such as age groups 26-35 years $(33 \%)$ and $36-45$ years $(50 \%)$. Almost all the participants were married except 9 of them. Only few of the respondents seems to be having steady income based on their employment as majority of them were self-employed rural people (48\%). Private or government employment is rarely evidenced among rural community of Sri Lanka which may be attributable to their low educational level and restricted access to information sources of potential employments them (Herath, Guneratne and Sanderatne, 2015). This is reflected by their educational level where only $29 \%$ of the respondents have reached their secondary level of education system in Sri Lanka. They become victims of their low educational background resulting poor social and economic status. This is confirmed by the income level of the respondents which is mostly cantered on an average of Rs. 20000.00. Rural community in general earns less relatively to the urban people (ADB, 2005). This then again has a cyclical effect on the lower social and economic development of them. Resultantly, they find it hard to get off from the trap of the poverty which is the ultimate aim of establishing the microfinancing institutions.

Having analysed the sample attributes, the researchers then tried in exploring the nature of the study variables. Two main descriptive measures namely, mean and the standard deviation were obtained and presented (Table 4).

Table 4. Descriptive Statistics of the Independent Variables

\begin{tabular}{|c|c|c|c|}
\hline Variable & $\mathrm{N}$ & Mean & $\begin{array}{c}\text { Std. } \\
\text { Deviation }\end{array}$ \\
\hline Income & \multirow{7}{*}{132} & 2.59 & .921 \\
\hline Literacy & & 2.57 & .867 \\
\hline $\begin{array}{l}\text { Receipt of social benefit } \\
\text { funds }\end{array}$ & & 3.22 & .892 \\
\hline $\begin{array}{l}\text { Demand for loan } \\
\text { securities }\end{array}$ & & 2.48 & .767 \\
\hline Interest charged & & 3.77 & 1.128 \\
\hline Service features & & 2.01 & .765 \\
\hline $\begin{array}{l}\text { Intention to obtain } \\
\text { credit facility }\end{array}$ & & 1.98 & .879 \\
\hline
\end{tabular}

Table 4 indicates that the level of borrower's income, literacy and receipt of social benefit funds were correspond to disagree level of the response scale. Further, loan attributes namely, demand for loan securities, interest charged, and service features were also at the disagree level. Moreover, the dependent variable; intention to obtain credit facility was also in the disagree level. All the variables showed a less variance implying the homogeneity of the responses among the respondents. These data implied that rural community experience hardships in their day to day life caused by lack of income, lack of knowledge about financing, and low literacy.

Many opportunists use these vulnerabilities in to their advantage and accordingly they are been cheated 
by various fraudulent activists. Resultantly, they compel to borrow at higher interest rates and unfavourable conditions without even knowing it. Their inability to reach the credit facilities of the commercial banks lead them to obtain credit from informal third parties under unfavourable conditions. Further, service features are also not sufficient as per their needs. Most of the respondents agreed that they could not obtain sufficient credit facilities due to their inability to present guarantees. Microfinancing expected to solve these complications experienced by the rural community and to facilitate them in fulfilling their financing needs. Yet, the records show that there is lower penetration to obtain credit facilities by the members of SPBSs in recent past. So as to ascertain the leads of the poor microfinance demand by the rural community, the association between predictor variables and the endogenous variable was tested using the Pearson's correlation analysis.

Correlation analysis showed the extent to which factors influenced and microcredit accessibility both variables vary together including the strength and direction of their relationship. The strength of the relationship refers to the extent to which independent variables relates with the demand for microfinance.
Table 5. Results of Correlation Analysis

\begin{tabular}{|l|c|c|}
\hline \multirow{2}{*}{ Variable } & \multicolumn{2}{|c|}{ Demand for Microfinance } \\
\cline { 2 - 3 } Coefficient & Significance \\
\hline Income & $-.689^{* *}$ & .000 \\
\hline Literacy & $.637^{* *}$ & .000 \\
\hline $\begin{array}{l}\text { Receipt of } \\
\text { Social benefit } \\
\text { funds }\end{array}$ & $-.756^{* *}$ & .000 \\
\hline $\begin{array}{l}\text { Interest } \\
\text { charged }\end{array}$ & $-.549^{* *}$ & .000 \\
\hline $\begin{array}{l}\text { Demand for } \\
\text { loan securities }\end{array}$ & $-.604^{* *}$ & .000 \\
\hline $\begin{array}{l}\text { Service } \\
\text { features }\end{array}$ & 0.710 & .000 \\
\hline
\end{tabular}

**. Correlation is significant at the 0.01 level (2-tailed)

The coefficients of Karl Person's Product Movement correlation analysis evidenced the relatedness of microfinance demand and the independent variables. Borrower's literary, and the service features of the credit facility found positively related to the demand for microfinance. Both literacy of the borrower $(r=0.637, p=$ $.000)$ and the service features of the loan facility $(\mathrm{r}=0.710, \mathrm{p}=.000)$ showed moderately related with the demand for microfinance. Both relationships evidenced to be statistically significant too. In contrast, borrower's income, receipt of social benefit funds by the borrower, interest charged, and demand for loan securities reported to be negatively correlated with the demand for microfinance. 
Specifically, borrower's income $(\mathrm{r}=$ $.689, \mathrm{p}=.000)$, interest charged $(\mathrm{r}=-$ $.549, \mathrm{p}=.000$ ), and demand for loan securities $(\mathrm{r}=-.604, \mathrm{p}=.000)$ found moderately associate with the microfinance demand. Importantly among the negatively correlated factors, receipt of social benefit funds by the borrower fund strongly and significantly related with microfinance demand $(\mathrm{r}=-.756, \mathrm{p}=$ .000 ). These findings aid in detecting the positive and negative determinants of microfinance demand of which the regression analysis was used to assess the magnitude of their influence.

The results of the regression analysis performed to test the hypotheses are illustrated by table 6 , table 7 , and table 8.

Table 6. Regression Analysis Model Summary

\begin{tabular}{|c|c|c|c|c|c|}
\hline Model & $\mathbf{R}$ & $\mathbf{R 2}$ & $\begin{array}{c}\text { Adjust } \\
\text { ed R }\end{array}$ & $\begin{array}{c}\text { Std. } \\
\text { Error }\end{array}$ & $\begin{array}{c}\text { Wurbi } \\
\text { Watso } \\
\mathbf{n}\end{array}$ \\
\hline 1 & $.773^{\mathrm{a}}$ & .615 & .028 & $\begin{array}{c}.5838 \\
9\end{array}$ & 2.011 \\
\hline
\end{tabular}

a. Predictors: (Constant), Income, Literacy, Receipt of social benefit funds, Interest, Demands for securities, Service features

b. Dependent Variable: Demand for microfinance

Table 7. Regression Analysis Model Significance

\begin{tabular}{|l|c|c|c|c|}
\hline \multicolumn{1}{|c|}{ Model } & $\begin{array}{l}\text { Sum of } \\
\text { Squares }\end{array}$ & Df & \multicolumn{1}{c|}{ f } & Sig. \\
\hline Regression & 30.352 & 6 & 64.636 & $.000^{\mathrm{b}}$ \\
\hline Residual & 22.617 & 125 & & \\
\hline Total & 49.969 & 131 & & \\
\hline
\end{tabular}

Source: Survey Results
Table 8 presents the magnitude of the influence by each predictor variable.

Table 8. Regression Analysis Coefficients

\begin{tabular}{|l|c|c|c|}
\hline \multirow{2}{*}{ Model } & $\begin{array}{c}\text { Standardized } \\
\text { Coefficient }\end{array}$ & $\mathbf{T}$ & Sig. \\
\cline { 2 - 4 } & $\mathbf{B}$ & & \\
\hline Constant) & 3.943 & 8.888 & .000 \\
\hline Income & -.183 & -3.869 & .031 \\
\hline Literacy & .172 & 2.873 & .040 \\
\hline $\begin{array}{l}\text { Receipt of social } \\
\text { benefit funds }\end{array}$ & -.238 & -5.279 & .008 \\
\hline Interest charged & -.104 & -2.076 & .036 \\
\hline $\begin{array}{l}\text { Demand for loan } \\
\text { securities }\end{array}$ & -.160 & -2.759 & .030 \\
\hline Service features & .211 & 4.724 & .042 \\
\hline Source: Survey
\end{tabular}

Source: Survey results

The results of multiple regression analysis those presented by table 6 , table 7 , and table 8 aided in developing the regression model to predict the demand for microfinance. The model satisfies the fundamental assumptions of a multiple regression where no auto correlation, and multicollinearity among the independent variables were noted. Further, dependent variable; the demand for microfinance resembled a normal distribution and the residuals are normally distributed. Accordingly, the developed model satisfactorily accounts $61.5 \%$ of the total variance of the microfinance demand. Both factors related to borrower and the factors related to lender/credit facility found significant at explaining the variance of the dependent variable. It implies that the demand for microfinance depend on the borrower's income $(\mathrm{B}=-.183, \mathrm{p}=$ $.031)$, literacy $(\mathrm{B}=.172, \mathrm{p}=.040)$, and receipt of social benefit funds by them $(\mathrm{B}=-.238, \mathrm{p}=.008)$. Additionally, all the tested factors related to lender / credit facility were also found 
significant in affecting the microfinance demand. Namely, the interest charged $(\mathrm{B}=-.104, \mathrm{p}=.036)$, demand for securities $(\mathrm{B}=-.160, \mathrm{p}=$ $.030)$, and the service features $(\mathrm{B}=$ $.211, \mathrm{p}=.042)$ reported to contribute in explaining the demand for microfinance. The above results supported all the hypotheses those assumed to be deciding the demand for microfinance; borrower's income $\&$ literacy, receipt of social benefit funds by them, interest charged by the microfinancing institutions, service features of the credit facility, and the demand for securities by the microfinancing institutions.

\section{DISCUSSION}

Rurual community find it hard in reaching the credit faciltites offered by commercial bank network due to unavailability of documentary proof on loan repayment ability, acceptable level of fix flow of income, loan securities and much more (Omboi and Wangai, 2011; Vetrivel and Kumarmangalam, 2010). These in constrast were supposed to be fliexble in terms of microfinaning lending so that rural peole would consider microfinancing as an accessible alternative to commercial banks' lending (Modoran, Grashof, Fernando and Tennakoon, 2009). Howerver, the results showed that microfinancing lending terms too are negatively affecting the demand for them. For instance, interest charged for microcredit facilities relative to the their income, was perceived high by the rural people. Hence, the interest charged is restaining the demand for microfinance (Auma and Mensah, 2014; Qatinah, 2013). Similarly, demanding loan securities by the microfinancing institutions was also appeared to be blocking the way towards obtaining microcredit. Identical findings are also reported in this connection (Modoran, Grashof, Fernando and Tennakoon, 2009). But this should not be the case with rural community as they got less/no valuables to be presented as securities.

Divergently, service features of the credit facility positively affecting the intention to obtain microfinance. Service features include support in completing documentation, translation of the terms of the loans into preferred languages, relaxation of required documentary evidences, offering mobile/ field services, providing one-to-one and / or group awareness...etc. Among the factors related to the borrower, income and receipt of social benefit funds (Samurdhi subsistence) were hindering the demand for microfinance (Tilakaratna, Wickramasinghe and Kumara, 2005). It's obvious for a wealthier to prevent been obtaining credit as long as he/she can manage their consumption and investment with the income. Moreover, for an unseen reason, in the Sri Lankan rural set up, many people don't want to be borrowers. This may be attributable the religious thoughts coming from the Buddhism. Accordingly, higher the income, lower will be the demand for any type of credit facility. Additionally, it is noteworthy to mention that the microfinance demand was greatly affected by the receipt of social benefit funds by the borrowers. These social benefit funds time-to-time were implemented via numerous social 
benefit programmes such as Janasaviya, Gamidiriya, and Samurdhi with the goal of raising the socioeconomical level of needy people. Even though no formal evidences on the success of these initiatives are available, it is seen that only very few portions of the recipients of these funds achieved a significant progress in their socio-economic status. Here of course, having money for managing the daily life discourage many needy people in obtaining microcredits for investment purposes. This issue seems to be having the roots in the lower psychological development of the rural people due to low educational background. Many preferred to satisfy with a low work and living profile rather than working hard to reach an upper level of socioeconomically status. This is further established as the greater literacy found pushing the demand for microfinance. Yet, it was noted that the majority of the respondents have poor level of literarcy due to their lower educational profiles (Kofarmata, Applanaidu and Hassan, 2016; Kausar, 2013).

All the results except receipt of social benefit funds by the borrower complies with the prevailing theoretical and empirical evidences. Thus, receipt of social benefit funds by the borrowers can be considered the maiden contribution of the present study.

\section{CONCLUSION}

The aim of the study was to identify the factors affecting the demand for microfinance in the context of Samurdi Prajamula Banking Societies. Two set of factors: factors related to borrower and the factors related to the lender/credit facility were teseted for thier relatedness to microfinance demand. Sample of rural people who are the members of SPBSs were surveryed. Results showed that the borrower's income, receipt of social benefit funds, demand for loan securities, and interest charged negatively affecting the microfinance demand while literacy of borrower, and the service features of the microcredit facility positively affecting the microfinance demand by the rural community.

The study succeeded in detecting the determinants of microfinance, particularly in the SPBSs context. The study was first to test the receipt of social benefit funds by the borrowers as a determinant of microfinance demand. Hence, the findings of the study hold greater theoretical and empirical implications for the scholars, practitioners, and to the policy makers in raising the microfinance demand. Administrators of microfinancing institutions especially that of the SPBSs, are requested to pay attention in revising unfavourable lending terms. Further, policy makers should reframe the aims and methodology of social benefit programme to minimize the potential adverse effect of them on the people's motivation to work for high-order development targets. Uplifting the knowledge and awareness of rural people too will effective in this regard. Future studies are invited to test the univariate influence of receipt of social benefit funds on the microfinance demand in depth so as to establish its position as a determinant of microfinance demand. 
Additionally, it would be worth enough to test the same argument though a different research approach: qualitative as every participant got unique story of financing their investments.

\section{REFERENCES}

Annual Report, 2005. Asian Development Bank.

Annual Report, 2005. Institute of Policy Studies of Sri Lanka.

Annual Reports, 2014-2016. Samurdhi Prajamula Banking Societies.

Auma, D. and Mensah, P., 2014. Determinants of Credit Access and Demand among Small-holder Farmers in Tigray Region, Ethiopia. Unpublished Master's Thesis. Norwegian University of Life Sciences, School of Economics and Business.

Balogun, O.L. and Yusuf, S.A., 2011. Determinants of demand for microcredit among the rural households in south-western states, Nigeria. Journal of Agriculture and Social Sciences, 7(2), pp.41-48.

Chen, G., Rasmussen, S. and Reille, X., 2010. Growth and vulnerabilities in microfinance (No. 56627, pp. 1-16). The World Bank.

Chowdhury, A., 2009. Microfinance as a poverty reduction tool: a critical assessment.
Cohen, J., 1992. A power primer. Psychological bulletin, 112(1), p. 155 .

Delfiner, M. and Peron, S., 2007. Commercial banks and microfinance.

Felloni, F. and McGrenra, D., 2013. Democratic Socialist Republic of Sri Lanka.

Fernando, S.N. and Madurapperuma, M.A.Y.D., 2009. The levels of financial sustainability and depth of outreach: Aa case of microfinance institutions in Sri Lanka. In: Academia., International Research Conference on Management and Finance, 12 December 2009 University of Colombo, Colombo. Sri Lanka: pp. 194204. Available at: https://www.academia.edu/870 1685 [Accessed January 20, 2018].

Herath, H.M.W.A., Guneratne, L.H.P. and Sanderatne, N., 2015. Impact of microfinance on women's empowerment: a case study on two microfinance institutions in Sri Lanka. Sri Lanka Journal of Social Sciences, 38(1), pp.51-61.

Hermes, N. and Lensink, R., 2007. The empirics of microfinance: what do we know?. The Economic Journal, 117(517), pp. F1-F10.

Institute of Policy Studies, 2005 
Kausar, A., 2013. Factors affect microcredit's demand in Pakistan.

$\begin{array}{lcr}\text { International } & \text { Journal } & \text { of } \\ \text { Academic } & \text { Research } & \text { in } \\ \text { Accounting, } & \text { Finance } & \text { and } \\ \text { Management } & \text { Sciences, } & 3(4), \\ \text { pp.11-17. } & & \end{array}$

Kimando, L., Kihoro, J.M.D. and Njogu, G.W.M., 2012. Factors influencing the sustainability of micro-finance institutions in Murang'a Municipality.

Kofarmata, Y.I., Applanaidu, S.D. and Hassan, S., 2016. Determinants of demand for credit: A conceptual review. Asian Journal of Economics and Empirical Research, 3(1), pp.6-10.

Modoran, C., Grashof, L., Fernando, R. and Tennekoon, A., 2009. Microfinance Institutions in Sri Lanka. Deutsche Gesellschaft für Technische Zusammenarbeit.

Mpuga, P., 2010. Constraints in access to and demand for rural credit: Evidence from Uganda. African Development Review, 22(1), pp.115-148.

Omboi, B.M. and Wangai, P.N., 2011. Factors that influence the demand for credit for credit among smallscale investors: a case study of Meru Central District, Kenya.

Qatinah, A.A., 2013. Factors Affecting Microfinance Demand and Supply Gaps in Yemen (Doctoral dissertation, Master Thesis, Phillipps University of Marburg).

Robinson, M.S., 2001. The microfinance revolution:
Sustainable finance for the poor. The World Bank.

Saunders, M., Lewis, P. and Thornhill, A., 2005. Research Methods for Business Studies.. New Dehli.

Tilakaratna, G., Wickramasinghe, U. and Kumara, T., 2005. Microfinance in Sri Lanka: A household level analysis of outreach and impact on poverty. Colombo: Institute of Policy Studies.

Ugwumba, C.O.A. and Omojola, J.T., 2013. Credit access and productivity growth among subsistence food crop farmers in Ikole Local Government Area of Ekiti State, Nigeria. Journal of Agricultural and Biological Science, 8(4), pp.351-356.

United Nations, 2015. Outcome Document of the United Nations Summit for the Adoption of the Post-2015 Development Agenda.

Vetrivel, S.C. and Kumarmangalam, S.C., 2010. Role of microfinance institutions in rural development. International Journal of Information Technology and Knowledge Management, 2(2), pp.435-441.

Wijewardena, W.A., 2003. Microfinance policy and regulatory framework: Experience and perspective of South Asian region-Sri Lanka, Bangladesh, Nepal and India.

Wrenn, E., 2007. Perceptions of the impact of microfinance on livelihood security. Research and 
Perspectives on Development Practice, 1.

Zeller, M., 1999, February. The role of micro-finance for income and consumption smoothing. In: $I A D B$ Conference on Social Protection and Poverty. 4 -5 February 1999 The Sustainable development department of the International American development Bank, 4 -5 February 1999 Washington, DC: pp. 1-26. 